\title{
Identification of Proximate Composition of Fermented Chicken Eggs by Using Lactobacillus plantarum with Different Incubation Times
}

\author{
Identifikasi Komposisi Proksimat Telur Ayam Ras Fermentasi Menggunakan Lactobacillus plantarum dengan \\ Waktu Inkubasi yang Berbeda
}

\author{
A. Mangalisu ${ }^{1 *}$, A. K. Armayanti ${ }^{1}$, I. I. Arief ${ }^{2}$, \& Z. Wulandari ${ }^{2}$ \\ ${ }^{1}$ Departemen Peternakan, Fakultas Pertanian, Universitas Muhammadiyah Sinjai \\ Jl. Teuku Umar No. 08 Kelurahan Biringere Kecamatan Sinjai Utara Kabupaten Sinjai, Sulawesi Selatan, \\ 92611, Indonesia \\ ${ }^{2}$ Departemen Ilmu Produksi dan Teknologi Peternakan, Fakultas Peternakan, Institut Pertanian Bogor \\ Jl. Agatis, Kampus IPB Darmaga Bogor 16680, Indonesia \\ *Corresponding author: azmimangalisu@gmail.com \\ (Received 17-10-2021; Revised 16-11-2021; Accepted 22-12-2021)
}

\begin{abstract}
Eggs that have a balanced amino acid content can fullfill protein that needs in humans, However, eggs have a low shelf life so they were easily damaged. Fermentation technology on foodstuffs by using microbes has been widely carried out, among others using Lactobacillus bacteria. The type of Lactobacillus bacteria commonly used in egg fermentation is Lactobacillus plantarum. This study was conducted experimentally by using a completely randomized design (CRD) with 3 treatments and 3 replications each. The treatment was carried out by fermentation with an incubation temperature of 37 ${ }^{\circ} \mathrm{C}$ with different incubation times of 0,48 , and 96 hours with research parameters water content, crude fat, crude fiber, BETN and ash content. The results showed that different incubation time treatments on fermented chicken eggs had a significant effect $(\mathrm{P}<\mathbf{0 . 0 5})$ on water content, crude fat, crude fiber, BETN and ash content. The nutritional composition of fermented eggs by using $L$. plantarum could be seen from the decrease in water content, crude fiber and BETN and an increase in crude fat and ash content with increasing incubation time. The value of water content, crude fat, crude fiber, BETN and optimum ash content at an incubation temperature of $37^{\circ} \mathrm{C}$ for 96 hours of incubation time.
\end{abstract}

Keywords: eggs, fermentation, L. plantarum, proximate analysis

\section{ABSTRAK}

Telur yang memiliki kandungan asam amino yang seimbang dapat memenuhi kebutuhan protein pada manusia, namun telur memiliki daya simpan yang rendah sehingga mudah mengalami kerusakan. Teknologi fermentasi pada bahan pangan dengan menggunakan mikroba telah banyak dilakukan antara lain dengan menggunakan bakteri jenis Lactobacillus. Bakteri jenis Lactobacillus yang umum digunakan pada fermentasi telur adalah Lactobacillus plantarum. Penelitian ini dilakukan secara eksperimental dengan menggunakan Rancangan Acak Lengkap (RAL) dengan 3 perlakuan dengan masing - masing 3 kali ulangan. Perlakuan tersebut dilakukan fermentasi dengan suhu inkubasi $37^{\circ} \mathrm{C}$ dengan waktu inkubasi yang berbeda yaitu 0, 48, dan 96 jam dengan parameter penelitian kadar air, lemak kasar, serat kasar, BETN dan kadar abu. Hasil penelitian menunjukkan perlakuan waktu inkubasi yang berbeda pada telur ayam fermentasi memberikan pengaruh yang nyata $(\mathrm{P}<0,05)$ terhadap kadar air, lemak kasar, serat kasar, BETN dan kadar abu. Komposisi Nutrisi Telur Fermentasi menggunakan $L$. plantarum dapat diketahui dari penurunan kadar air, serat kasar dan BETN dan terjadi peningkatan lemak kasar dan kadar abu seiring meningkatnya waktu inkubasi. Nilai kadar air, lemak kasar, serat kasar, BETN dan kadar abu optimum pada suhu inkubasi $37^{\circ} \mathrm{C}$ selama 96 jam waktu inkubasi.

Kata kunci: analisis proksimat, fermentasi, L. plantarum, telur 


\section{INTRODUCTION}

Eggs provide the largest contribution of animal protein to the community because apart from relatively cheap prices and easy availability of eggs. Eggs that have a balanced amino acid content can fullfil protein that needs in humans, but the presence of abundant eggs causes side effects for the eggs themselves. Eggs will be damaged if the shelf life is too long. There are various ways that can be done so that the shelf life of eggs can be extended, one of them is fermentation.

Fermentation technology is carried out to obtain benefits as functional food that is good for health, facilitates digestive absorption and extends product shelf life. Fermentation technology in foodstuffs by using microbes has been widely carried out, among others, using Lactobacillus bacteria. Lactobacillus type bacteria commonly used in egg fermentation is Lactobacillus plantarum. These bacteria can grow by requiring the nutritional value contained in the growth medium.

L. plantarum bacteria are proteolytic bacteria that can convert protein compounds into simpler compounds (Nahariah et al. 2015). L. plantarum bacteria grows in one medium if the ability to metabolize nutrients is well developed and during growth the ability to break down proteins into amino acids is maintained for cell proliferation (Nisa et al. 2008). During the fermentation process, L. plantarum will produce metabolites such as lactic acid, hydrogen peroxide, and bacteriocins that function as antibacterial compounds (Mahon et al. 2015). Bacteriocins are peptides or protein compounds that are released into the extracellular by lactic acid bacteria and have a bactericidal effect towards harmful bacteria that are closely related phylogenetically (Urnemi et al. 2011). The presence of this antibacterial activity can be used to prevent the development of pathogenic bacteria.

Bacteriocins have long been identified by researchers and are considered natural products in the form of proteins or peptides from bacteria in fermentation products. Lactobacillus plantarum is one of the lactic acid bacteria that has ability to produce lactic acid and degrade the nutritional content of eggs thus, it has the ability to produce bacteriocins which also have antibacterial properties. The purpose of this study was to identify the proximate contents of fermented chicken eggs by using L. plantarum bacteria.

\section{MATERIALS AND METHODS}

\section{Material}

The equipment used in this study were sample tubes, erlenmeyer, micropipette, tip, syringe, analytical balance, measuring cup, incubator, spatula, autoclave, magnetic stirrer, vortex, lamina air flow, hot plate, khedjal flask, fume hood, measuring flask, distillation flask, centrifuge, spectrophotometer (Thermo Genesys 20). The materials were mass chicken eggs, Lactobacillus plantarum bacterial culture, MRS (Man Rogosa Sharpe) broth, aluminum foil, tomato juice, distilled water, alcohol, $\mathrm{H}_{2} \mathrm{SO}_{4}$, distilled water, $\mathrm{H}_{3} \mathrm{BO}_{3}$, $\mathrm{NaOH}, \mathrm{TCA}$, lowry reagent, folin reagent, BSA solution.
This study was conducted experimentally by using a completely randomized design (CRD) with 3 treatments and 3 replications each. The treatment was carried out by fermentation with an incubation temperature of $37^{\circ} \mathrm{C}$ with different incubation times of 0,48 , and 96 hours.

\section{Methods}

\section{Culture Propagation}

Lactobacillus plantarum was stored on De Man Ragosa Sharpe (MRS) agar. Propagation of culture by making sub-cultures. Sub-culture was made by transferring the culture stock into liquid medium of MRS broth (OXOID CM0359) to which $20 \%$ tomato juice was added and incubated for 24 hours (Pramono et al. 2003). Cultures that had been stored in MRS broth media were inoculated as much as $10 \%$ into egg whites containing $20 \%$ tomato juice to produce working cultures (Nahariah et al. 2013).

\section{Sample Preparation}

Egg samples were cleaned using clean water. The eggs were then fumigated by using Calcium Permanganate (CP) powder and formalin in a closed room for 5 minutes and successively cleaned by using a wet cloth, chlorine solution and wiped with alcohol by using a cotton swab. Eggs were wrapped in aluminum foil and pasteurized at 60 ${ }^{\circ} \mathrm{C}$ for 3,5 minutes (Froning et al. 2002) then separated from the shell and then put into a sample bottle. The sample bottles were first cleaned by using warm water and sterilized. 100 ml sample was homogenized and then sterilized by using ultraviolet by placing it in a PCR Hood for 15 minutes. The sterile sample was added with $10 \mathrm{ml}$ of working culture $\left(10^{6} \mathrm{CFU} / \mathrm{ml}\right)$ and then homogenized with a tube shaker, the sample was then fermented according to the research treatment (Nahariah et al. 2015).

\section{Tested Parameters}

\section{Water Content}

Prepare a porcelain dish that had been cleaned in an oven at a temperature of $105^{\circ} \mathrm{C}$ for 2 hours. Then it was cooled in a desiccator for hour and then weighed (a gram). Put the sample into a porcelain cup and weigh \pm 1 gram of the sample (b gram). Next, to bake at $105^{\circ} \mathrm{C}$ for 8 hours or leave overnight. Remove from oven and cool in desiccator for $1 / 2$ hour then weigh (c gram) with the following calculation:

$\%$ Dry Ingredients $\quad=\quad \frac{\mathrm{C}-\mathrm{A}}{\mathrm{B}} \times 100 \%$
$\%$ Water $=100 \%-\%$ Dry Ingredients

\section{Crude Fat}

Weigh \pm 1 gram of the sample then put it into a 15 $\mathrm{ml}$ test tube and added chloroform to a $10 \mathrm{ml}$ scale and after that shaked it and let it cool overnight. Squeeze up to $10 \mathrm{ml}$ with chloroform and shake again. Filtered with filter paper into a test tube. Pinch $5 \mathrm{ml}$ into a cup of known weight (a gram) and oven at $100{ }^{\circ} \mathrm{C}$ for 4 hours. After that, took it out from the oven and cold it in a desiccator for $1 / 2$ hour then weigh it (b gram). The calculation is as follows: 


$\begin{aligned} \% \text { Crude Fat } & =\frac{\mathrm{P} \times(\mathrm{b}-\mathrm{a})}{\text { Sample Weight }} \times 100 \% \\ \mathrm{P} & =\text { Dilution }(10 / 5)\end{aligned}$

\section{Crude Fiber}

Weigh \pm 0.3 sample into a $50 \mathrm{ml}$ test tube and added $30 \mathrm{ml}$ of $0.3 \mathrm{~N} \mathrm{H}_{2} \mathrm{SO}_{4}$ and heat for 30 minutes. After that added $15 \mathrm{NaOH} 1.5 \mathrm{~N}$ and heat for 30 minutes. Strain into sintered glass No. 1 while sucked by using a vacuum pump. Washed successively with $40 \mathrm{ml}$ of hot water, $40 \mathrm{ml}$ of 0.3 $\mathrm{N} \mathrm{H}_{2} \mathrm{SO}_{4}, 40 \mathrm{ml}$ of hot water and $10 \mathrm{ml}$ of acetone. Then dried in the oven for 8 hours or leave overnight. After that, cold in desiccator for hour then weigh (a gram). After that, the sample was ashed into an electric furnace for 3 hours at a temperature of $500{ }^{\circ} \mathrm{C}$. Let the sample cool a bit then put it in the desiccator for $1 / 2$ hour then weigh it (b gram). The calculation is as follows:

$$
\% \text { Coarse Fiber }=\frac{\mathrm{A}-\mathrm{B}}{\text { Sample Weight }} \times 100 \%
$$

\section{BETN}

The way to get the value of the Nitrogen-Free Extract (BETN) is with the formula:

$\mathrm{BETN}=[100-($ Ash Content + Crude Fiber Content + Crude Fat Content + Crude Protein Content) 100\%]

\section{Ash Content}

Porcelain dish and the sample in determining the water content, it was inserted into the electric furnace. The temperature of the kiln was set to $600{ }^{\circ} \mathrm{C}$, then left for 3 hours to turn into ashes (to speed up the ashing process, once the kiln was opened). Cold the porcelain dish into the desiccator for $1 / 2$ hour then weigh ( $d$ gram). Calculation as follows:

$$
\% \mathrm{Ash}=\frac{\mathrm{D}-\mathrm{A}}{\mathrm{B}-\mathrm{A}}
$$

\section{RESULTS AND DISCUSSION}

The proximate composition of fermented chicken eggs by using different incubation times can be seen in Table 1 .

\section{Water Content}

Table 1 showed that the proximate composition of fermented chicken eggs with different incubation times had a significant $(\mathrm{P}<0.05)$ effect on water content. Moisture content decreased with increasing incubation time.
This was presumably because the metabolic products of $L$. plantarum including water decreased with incubation time. Different incubation time treatments for fermented chicken eggs resulted in the lowest water content value at 96 hours treatment, which was $80.32 \%$, while the highest at 0 hours treatment was $81.61 \%$. This showed that the longer the incubation time, the lower the amount of water content produced. Moisture content was water content which was the result of metabolism resulting from the fermentation process, the more L. plantarum grows, the higher the metabolic results (Purnomo et al. 2003). Several studies on fermentation with L. plantarum were carried out by (Syahrir 2002) on cow's milk curd which produced a water content of $73.02 \%$ during 48 hours of fermentation. The use of $L$. plantarum bacteria in the fermentation of milkfish paste produced a water content of $73.01 \%$ after 5 days of fermentation (Zummah et al. 2013).

The high water content at incubation time of 0 hours was thought to be due to the metabolic activity of L. plantarum. Incubation time would produce amylolytic activity of lactic acid bacteria due to an increase in the number of L. plantarum bacteria. Amylolytic activity would be able to hydrolyze simple proteins, with protein hydrolysis, more glucose and other sugars would be produced, then the glucose and sugar would be converted into pyruvate by liberating water molecules, so that the water content was also higher (Zummah et al. 2013).

\section{Crude Fat}

The results of the proximate analysis (Table 1) showed that the incubation time treatment had a significant effect $(\mathrm{P}<0.05)$ on crude fat. Further test results showed that the higher the incubation time the amount of crude fat also increased. This was presumably due to a decrease in water content at the time of increasing incubation time indicating that the bacteria were able to utilize the protein present in the egg so that it did not remodel the crude fat reserves in the egg. The results showed that the longer the incubation time, the higher the crude fat value. This was in line with the opinion of Sitio (2019), that crude fat content would increase along with the increase in fermentation time.

\section{Coarse Fiber}

The results showed a significant effect $(\mathrm{P}<0.05)$ on the crude fiber of fermented chicken eggs. The amount of crude fiber at 0 hours of incubation showed the highest value of $0.5 \%$ and decreased with increasing incubation time of 96 hours giving a value of $0.2 \%$. The decrease in the number along with the increase in incubation time was thought to be due to the fermentation process that occured in chicken eggs causing a decrease in the amount of crude fiber. This was in

Table 1. The proximate composition of fermented chicken eggs with different incubation times

\begin{tabular}{cccccc}
\hline \multirow{2}{*}{ Incubation Time (hours) } & \multicolumn{5}{c}{ Proximate Composition (\%) } \\
\cline { 2 - 6 } & Water content & Crude Fat & Crude Fiber & BETN & Ash Content \\
\hline 0 & $81.61 \pm 0.31 \mathrm{c}$ & $4.33 \pm 0.05 \mathrm{a}$ & $0.50 \pm 0.00 \mathrm{c}$ & $4.17 \pm 0.12 \mathrm{~b}$ & $0.72 \pm 0.01 \mathrm{a}$ \\
48 & $80.94 \pm 0.03 \mathrm{~b}$ & $5.51 \pm 0.12 \mathrm{~b}$ & $0.33 \pm 0.06 \mathrm{~b}$ & $4.03 \pm 0.23 \mathrm{~b}$ & $0.73 \pm 0.00 \mathrm{~b}$ \\
96 & $80.32 \pm 0.09 \mathrm{a}$ & $5.93 \pm 0.01 \mathrm{c}$ & $0.20 \pm 0.00 \mathrm{a}$ & $2.37 \pm 0.23 \mathrm{a}$ & $0.75 \pm 0.00 \mathrm{c}$ \\
\hline
\end{tabular}

Description : Different superscripts in the same column showed significant differences $(\mathrm{P}<0.05)$. 
line with the opinion of Sitio (2019), that the fermentation process caused the microorganisms contained in probiotic supplements to be able to break down long-chain carbohydrates, proteins, and fats. The breakdown of long chains of carbohydrates, proteins and fats made complex molecule meals simple.

\section{BETN}

The results of the proximate analysis showed that the different incubation time of the Nitrogen-Free Extract (BETN) had a significant effect $(\mathrm{P}<0.05)$. The highest number of BETNs was found at 0 hours of incubation with a value of $4.17 \%$, while the lowest number of BETN was found in 96 hours of treatment, which was $2.37 \%$. The decrease at different incubation times was due to the longer incubation time, the lower the BETN value.

The decrease in BETN levels at $96 \%$ incubation time occurred because the crude fiber of fermented eggs also decreased. This was in accordance with the opinion of Tillman et al. (1991) that a decrease in the crude fiber content of a material would reduce the BETN content. Inversely proportional to the incubation time of 0 hours giving a high amount of BETN in line with the high amount of crude fiber in the treatment of 0 hours so it would give a high BETN value as well.

\section{Ash Content}

Table 1 showed the results of the proximate analysis of fermented chicken eggs with different incubation times that significantly affected $(\mathrm{P}<0.05)$ on the amount of ash content. Further test results showed that the higher the incubation time, the higher the amount of ash content. This was presumably because the metabolic activity of L. plantarum bacteria in eggs had not been maximized, resulting in an increase in ash content. This was in line with the decrease in water content in this study so that it would have a side effect of increasing the amount of ash content in fermented eggs. The work of L. plantarum bacteria decreased with the length of incubation time because the longer the incubation time, L. plantarum bacteria were not able to metabolize optimally. This was in accordance with the opinion of Sitio (2019), that the change in the amount of ash content was caused by bacterial activity during the fermentation process.

\section{CONCLUSION}

The eggs fermentation cause some changes in nutritional composition such as decreasing water content, crude fiber and BETN, and increasing crude fat and ash content during the increasing incubation time. The value of water content, crude fat, crude fiber, BETN and optimum ash content at an incubation temperature of $37{ }^{\circ} \mathrm{C}$ for 96 hours of incubation time.

\section{ACKNOWLEDGEMENT}

This study is part of National Competitive Research Scheme for Higher Education Cooperation from Directorate of Research and Community Service of Ministry of Education and Culture, Research and Technology in 2021, so we thank Ministry of Education and Culture, Research and Technology for the financial assistance so that this study is carried out. We also thank IPB Unversity as the Advisory Team.

\section{REFERENCES}

Froning, G. W., D. Peters, P. Muriana, K. Eskridge, D. Travnicek, \& S. S. Sumner. 2002. Internasional egg pasteurization manual. United Egg Producers. Washington.

Mahon, C. R., C. D. Lehman, \& G. Manuselis. 2015. Textbook of Diagnostic Microbiology $5^{\text {th }}$ Edition. Missouri. Saunders Elsevier.

Nahariah, A. M. Legowo, E. Abustam, A. Hintono, Y. B. Pramono, \& F. N. Yuliati. 2013. Kemampuan tumbuh bakteri Lactobacillus plantarum pada putih telur ayam ras dengan lama fermentasi yang berbeda. JITP. 3(1):33-39.

Nahariah, A. M. Legowo, E. Abustam, \& Hintono. 2015. Angiotensin I-Converting Enzyme Inhibitor Activity on Egg Albumen Fermentation. Asian Australas. J. Anim. Sci. 28(6):855-861.

Nisa, F. C., J. Kusnadi, \& R. Chrisnasari. 2008. Viabilitas dan deteksi subletal bakteri probiotik pada susu kedelai fermentasi instan metode pengeringan beku (kajian jenis isolate dan konsentrasi sukrosa sebagai krioprotektan). Jurnal Teknologi Pertanian. 9(1):40-51.

Pramono, Y. B., E. Harmayani, \& T. Utami. 2003. Kinetika pertumbuhan Lactobacillus plantarum dan Lactobacillus sp pada media MRS cair. Jurnal Teknologi dan Industri Pangan. 14(1):46-50.

Sitio, A. B. 2019 Analisis kandungan Proksimat Pakan Organik yang Diberi Suplemen Probiotik $\mathrm{H}^{* *}$ dan Pengaruhnya Terhadap Berat Ayam Bangkok. Skripsi. Yogyakarta.

Syahrir, I. H. 2002. Karakteristik Fisik, Kimia dan Mikrobiologi Dadih Susu Sapi dengan Kombinasi Starter Lactobacillus plantarum, Lactobacillus bulgaricus dan Streptococcus termophillus. Skripsi. Institut Pertanian Bogor. Bogor.

Tillman, A. D., S. Reksohadiprodjo, S. Prawirokusumo, H. Hartadi, \& S. Lebdosoekojo. 1991. Ilmu Makanan Ternak Dasar. Gadjah Mada University Press. Yogyakarta.

Urnemi, S. Syukur, E. Purwati, S. Ibrahim, \& Jamsari. 2011. Potensi bakteri asam laktat dalam menghasilkan bakteriosin sebagai antimikroba dan pengukuran berat molekulnya dengan SDS-PAGE dari isolat fermentasi kakao. J Ris Kim. 4(2):94-100.

Zummah, A., \& P. R. Wikandari. 2013. Pengaruh waktu fermentasi dan penambahan kultur starter bakteri asam laktat Lactobacillus plantarum B1765 terhadap mutu bekasam ikan bandeng (Chanos chanos). UNESA J of Chemistry. 2(3):14-24. 